\title{
Gastric Cancer pN1 TNM Finding v6
}

National Cancer Institute

\section{Source}

National Cancer Institute. Gastric Cancer pN1 TNM Finding v6. NCI Thesaurus. Code C61193.

Gastric cancer with evidence of metastasis in 1-6 regional lymph nodes. (from AJCC 6th Ed.) 